\title{
THE EFFECT OF INTERMITTENT TRAINING WITH PLYOMETRIC EXERCISES ON AEROBIC AND ANAEROBIC CAPACITIES
}

\author{
Benrabah Kheiredine ${ }^{1}$, Bensassi Radhouane ${ }^{2}$, Charef Silarbi ${ }^{3}$, Bennadja Mohamed ${ }^{4}$, Kharoubi \\ Mohamed Fayçal ${ }^{5}$ and Kacem Abdelhadi ${ }^{6}$ \\ 1-2-3-4-6Institute of Sciences and Techniques of Physical and Sports Activities(STAPS)- University of \\ Tissemsilt, Algeria \\ ${ }^{5}$ Institute of Physical Education and Sports-University of Algiers 3, Algeria
}

UDK 796.015.15

796.332

\section{SUMMARY}

This study check the effectiveness of the intermittent work as a key method of work of the quality in the quantity by the layout of a plyometric work. The question always remains to find the training methods scientifically validated which lead to improve these qualities. We put forward the hypothesis that the intermittent training by plyometric exercises will improve the football players, aerobic an anaerobic capacities.

Twenty football players aged between 18 and 23 years coming from Tissemsilt university team were invited to participate in our study (table1). Our population was spilt up into 2 groups in a random way. An experimental group (EG) and control group (CG). The programme was calibrated on 8 weeks and planned as follow: two weeks of intermittent work $10 \mathrm{~s} / 20 \mathrm{~s}$, four weeks of intermittent work 30s/30s, two weeks of intermittent work 15s/30s. The frequency of these types of training was 2 sessions/week. The footballers did a physical tests: (SJ; CMJ). The (RSA) test, and the Yo-yo test. The tests were again proposed to the footballers: this allowed us to compare the obtained results between the two tests before and after the training.

After eight weeks of training, we recorded a development in the experimental sample in the (MAS), vertical jump (CMJ), and (RSA) tests, while we did not record a significant difference in the vertical jump (SJ) test $(\mathrm{p}<0.05)$, As with the control sample, the development was limited to (MAS) and (RSA) only. 
This study shows the effectiveness of the training programme applied to the experimental sample in the post-tests between the two groups, with the exception of the vertical jump test (SJ), where there was no significant difference.

Keywords: Intermittent, Plyometric, Exercises, Aerobic, Anaerobic.

\section{INTRODUCTION}

The football is a sport which combines specific techniques (dribbling, kicking, direction change) with intense intermittent periods of running and walking (F.M. et al., 2009)-(J. Bangsbo, 1994).

The match analysis studies showed that the football needed to produce a lot of short perioded maximal and nearly maximal actions with brief periods of recuperation (Spencer et al., 2005)-(Withers et al., 1982). For these reasons, the football training must generally include exercises aiming at improving both the aerobic capacity and the anaerobic capacity. Moreover, the football needs the execution of short intense actions, linked together and interposed by an interval of rest. This kind of sport requires qualities of force, speed and of resistance to repeat maximal actions "Repeat Sprint Ability".

The intermittent exercises would constitute a training methodology very close to the players activity recorded during a match. This type of exercise allows to work for a long time, longer than a continuous work to a similar intensity while limiting the accumulation of lactate (Gaitanos et al., 1993), because a part is metabolized during the time of recuperation (BALSOM et al., 1995). Moreover, the intermittent training can also be efficient to improve the vo2 max and the aerobic activity (Burgomaster et al., 2005)-(Dawson et al., 1998)-(Harmer et al., 2000)(Linossier et al., 1997)-(Macdougall et al., 1998)-(Parra et al., 2000)-(Rodas et al., 2000). From now, the solicitation of the lactic anaerobic metabolizm is inescapable. The solicitation to this stream during the exercises generates however a number of questions and controversies for the coach and the physical assistants who enquire about the risks related to this type of exercises especially if it is done in a plyometric form (G Dupont et al., 2000), during the brief intermittent actions interposed by short periods of recuperation. The passive recuperation allows to maintain the exercise for a long time, longer than when the recuperation is active (Grégory Dupont et al., 2005).

One of the physical abilities which constitutes a determinant factor of the sporty performance is the capacity to link together sprints and quick brief movements of explosive force nature without losing neither the quality (the quality of technical gesture and speed of the sprint execution) nor the effectiveness (the level of the physical layout and the distance covered) (Bishop et al., 2011). However, the power, the spring and the agility are often important in 
the critical moments of the game (Canavan \& Vescovi, 2004), mentions that the power of the lower limbs and in particular the vertical spring is considered as a crucial element for the athletic performance. The force and the power share the importance with the endurance in the soccer of high level. Two different mechanisms, the muscular hypertrophy and the neural adaptations are central in the development of the muscular force (Stølen et al., 2005).

The plyometrics is one of training methods recommended for the improvement of the power in the spring and in the run speed (Kotzamanidis, 2006). It leads to the improvement of the performance, particularly in the activities requiring explosive muscular contractions. The training of plyometrics was advocated as an appropriate approach for the sport which requires the explosivity and the improvement of the vertical spring (De Villarreal et al., 2008)(Rahimi, 2005), indicates the training of the plyometrics of a short time is capable to improve the vertical spring, the muscular force and the anaerobic power, the training in plyometrics provokes an increase in the muscular stiffness (Spurrs et al., 2003), is strongly correlated to the performance in repeated sprints (RSA) (Balsom et al., 1992).

The purpose of this study is to check the effectiveness of the intermittent work as a key method of the work of the quality in the quality by the layout of a plyometric work, the question always remains to find the training methods scientifically validated which lead to improve these qualities. We put forward the hypothesis that the intermittent training by plyometric exercises will improve the aerobic and anaerobic aptitude of the football players.

\section{MATERIAL AND METHODS}

\subsection{Study subjects}

Twenty footballers aged between 18 and 23 years, coming from Tissemsilt university team, were invited to participate in our study. The average age of the subjects was of 20,73 $\pm 2,61$ (average \pm standard deviation) years, that of the height was of $172,93 \pm 2.54 \mathrm{~cm}$. The average weight of all the players was of 75,78 $\pm 3,5 \mathrm{~kg}$. None of the participants was a former or current smoker or was using medication and none had a history of disease or injury that would prevent physical activity. A medical examination was applied to each participant prior to inclusion, revealing no contraindication to physical exercise. All participants provided selected information on life style factors and medical history. All subjects participated in the study during the off-season period, when they were not intending to participate in any races within 3 months at the beginning of an experimental period. All the participants were informed of the testing protocol. 


\subsection{Study protocol}

The protocol was conducted from Mars to May 2019. The temperature varied between $17^{\circ} \mathrm{C}$ and $23^{\circ} \mathrm{C}$ and the humidity ranged from $70 \%$ to $75 \%$. Participants were familiarized with different exercises and tests during the week preceding training programme onset. They had indices of body composition and physical testing. For the purposes of the protocol, we divided the group into an experimental group (EG) and a control group (CG) of 10 players respectively were thus created, at the beginning of the experimental protocol there was no significant difference between the two groups for anthropometric data (Tab1). Anthropometric data (Tab1) were collected using a conventional scale and a standard measurement scale, and body mass index was calculated as the quotient of body mass $W(\mathrm{~kg})$ to height squared $\mathrm{H}\left(\mathrm{cm}^{2}\right)$. Subjects were assessed at two different moments, before the start of the training period (pre-training, T1) and after 8-week of training (post-training, T2). The T1 and T2 assessments were divided over 3 days with an interval of $48 \mathrm{~h}$.

Table 1. Demographic characteristics of study sample

\begin{tabular}{lllll}
\hline Sample & Age & Height $(\mathbf{c m})$ & Weight $(\mathbf{k g})$ & BMI \\
\hline $\begin{array}{l}\text { Experimental } \\
\text { group }\end{array}$ & $20.85 \pm 2.2$ & $172.4 \pm 3.4$ & $76.4 \pm 3.1$ & $24.3 \pm 2.1$ \\
Control group & $20.61 \pm 1.8$ & $173.46 \pm 2.9$ & $75.16 \pm 3.6$ & $24.5 \pm 1.8$ \\
\hline
\end{tabular}

Note: BMI - Body Mass Index = Weight $(\mathrm{kg}) /$ Height $\left(\mathrm{cm}^{2}\right)$.

\subsection{Training programme}

The group (EG) did a training programme of intermittent work with plyometric excercises, these exercises showed different forms of jumps and vertical and horizontal bound. The sessions of training were carried out in the field and the intensity was controlled according to the time and the distance covered. The intermittent sessions were organized according to the Cometti philosophy: Intermittent power, Intermittent speed and intermittent Mixed. The calibrated programme on 8 weeks and planned as 2 weeks of intermittent work $10 \mathrm{~s} / 20 \mathrm{~s}$ allows to do neuromuscular work, it has an anaerobic character in lactic power while maintaining aerobic power. 4 weeks of intermittent work 30s/30s. The 30s/30s is a neuromuscular work with a great demand on energy reserves. In 30 s/30s l'O2 is used at $40 \%$ for those who have aerobic skills and only $29 \%$ to $35 \%$ in subjects with anaerobic skills It is a work protocol of a glycolytic nature in capacity but which will contribute mainly to the development of aerobic power (L. V. Billat, 2001), and two weeks of intermittent work 15s/30s. The $15 \mathrm{~s} / 30 \mathrm{~s}$ is a niche that promotes the development of moderate neuromuscular work. It has an anaerobic character in lactic capacity while developing aerobic power. The 
frequency of these types of training was 2 sessions /week. The training load gradually increases during each intermittent slot. A week of sharpening is ensured after each 3 week cycle to reduce the negative physiological and psychological effects that are built up during the intermittent mode that precedes sharpening and thus allow the athlete to recover. This reduction in the training load is the result of a reduction in the training frequency (30\% to $50 \%)$ and a decrease in the duration of the sessions (50\% to $90 \%)$ but the intensity of the exercise remains the same in order to maintain the positive adaptations caused by training (Mujika \& Padilla, 2003). Recovery between repetitions was passive since it was shown that the Time Limit was longer when intermittent exercises were interspersed with passive recovery than active. Consequently, during brief intermittent runs interspersed with short recovery periods, passive recovery makes it possible to maintain the exercise longer than when recovery is active (Grégory Dupont et al., 2005). The recovery between series is 7 to 10 minutes. It is a relatively long period to allow the effort that follows to be qualitative. In order to avoid a significant drop in heart rate, important complementary physical qualities were performed: abdominal strengthening, muscle stretching (L. V. Billat, 2001). The control group (CG) worked only the intermittent method without the plyometric exercises with the same programme with the experimental group. To assess the effect of this programme We have made reliable and specific physical tests (Yo-yo, SJ, CMJ, and RSA test) done with the experimental group and the control group before and after the training programme.

\subsection{Physical tests}

\subsubsection{Repeated sprint ability test (RSA)}

Repeated sprint ability test players performed a test consisting of six 30m (15 $+15 \mathrm{~m}$ ) sprints interspersed with 14-second breaks. Players started from a line, sprinted for $20 \mathrm{~m}$, touched the line with a foot, and returned to the starting line as fast as possible. The best race time is a reference for calculating the Repeated sprint abilityin the form of decay score S dec $(\%)=(-1) 100$ (Girard et al., 2011). The time was measured using a chronometer.

\subsubsection{Vertical jump measures}

Vertical jumpt he measurements of vertical jump performance was assessed by using a portable force platform (myotest, Finland). Players performed counter movement jump (CMJ) and squat jumps (SJ) according to the protocol described by (Carmelo Bosco et al., 1983). Before testing, the players performed selfadministered submaximal CMJs and SJs (2-3 repetitions) as a practice as well as additional warm-up. During testing, the players were asked to keep their hands on their hips to prevent any influence of armmovements on the vertical jumps and to avoid coordination as a confounding variable in the assessment of the 
legextensors (C. Bosco et al., 1995). Each subject performed 3 maximal CMJs and SJs with approximately 2 minutes' recovery time between them. The players were asked to jump as high as possible; the highest jump was then recorded in centimetres (C. Bosco et al., 1995). The specific power (P) analyzed in the continuous rebound tests and calculated by the system software is obtained by the following formula: P (watt) = g2.Rtv (Rtv + Rtc) / 4.N Jumps.

\subsubsection{Yo yo test}

The Yo-Yo intermittent recovery test consists of repeated $2 \times 20$ m runs back and forth between the starting, turning, and finishing line at a progressively increased speed controlled by audio bleeps from a tape recorder (Krustrup et al., 2003).

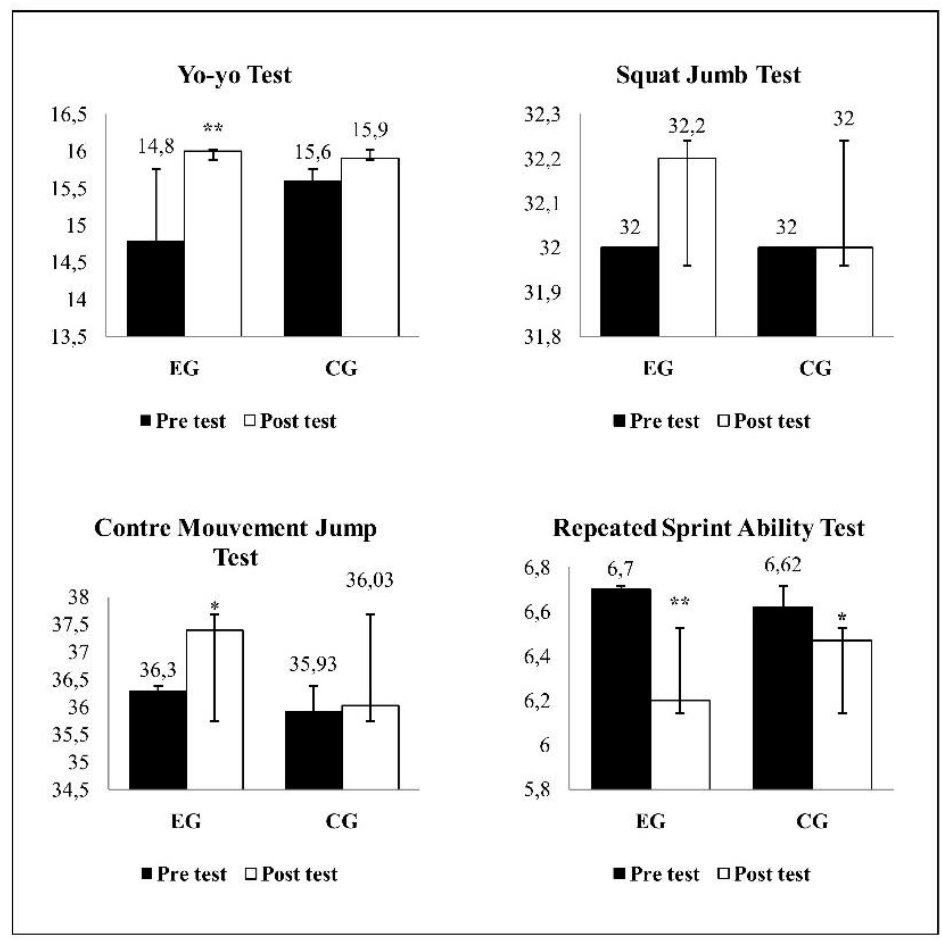

Figure 1: Shows the Results obtained by the physical tests done with the experimental group and the control group before and after the training programme.

Between each running bout, the subjects have a 10 -s active rest period, consisting of $2 \times 5 \mathrm{~m}$ of jogging. When the subjects twice have failed to reach the finishing line in time, the distance covered is recorded and represents the test result. The test may be performed at two different levels with differing speed profiles (level 1 and $2)$. In the present study, we used the Yo-Yo intermittent recovery test, level 1, the two Yo-yo intermittent recovery (IR) tests evaluate an individual's ability to 
repeatedly perform intense exercise. The Yo-yo IR level 1 (Yo-yo IR1) test focuses on the capacity to carry out intermittent exercise leading to a maximal activation of the aerobic system, whereas Yo-yo IR level 2 (Yo-yo IR2) determines an individual's ability to recover from repeated exercise with a high contribution from the anaerobic system. Evaluations of elite athletes in various sports involving intermittent exercise showed that the higher the level of competition the better an athlete performs in the Yo-yo IR tests. Performance in the Yo-yo IR tests for young athletes increases with rising age. The Yo-yo IR tests have shown to be a more sensitive measure of changes in performance than maximum oxygen uptake. The Yo-yo IR tests provide a simple and valid way to obtain important information of an individual's capacity to perform repeated intense exercise and to examine changes in performance (Jens Bangsbo et al., 2008).

\subsection{Statistical analysis}

In this study, two groups (EG and CG) followed a protocol of 8 weeks of separate training but of equivalent load. The dependent variables used adapted SJ and adapted CMJ, anthropometric measurements, Yo yo test and RSA test are metric variables and were evaluated twice on the same subjects. The aim being to show the effectiveness of the protocol on the dependent variables, in the two groups (GE and CG). After verifying parametric test conditions (homogeneity of variances and normality of distribution), a factor ANOVA for repeated measurements (intra factor) was used. An intergroup comparison, an intragroup comparison and the effects of [(Group vs Condition), (pre-training vs posttraining)] interactions were studied. To perform all of our statistical processing, we used SPSS.0.20 software. The significance threshold for all the results was set at $\mathrm{P}<0.05$.

\section{RESULTS}

Table 2: Results obtained by the physical tests done with the experimental group and the control group before and after the training programme.

\begin{tabular}{lllllll}
\hline Sample & Tests & Pre test & Post test & T test & P value & Sig \\
\hline \multirow{4}{*}{ Experimental } & Yo-yo (MAS) & $14.8 \pm 0,91$ & $16.0 \pm 0.78$ & 03.22 & & 0.0012 \\
group & S & $32,0 \pm 1,8$ & $32,2 \pm 2,0$ & 0.86 & & 0.0681 \\
& CMJ & $36,3 \pm 1,53$ & $37.4 \pm 1.82$ & 2.22 & & 0.0328 \\
& RSA test & $6,7 \pm 0,28$ & $6.2 \pm 0.48$ & 3.01 & \multirow{2}{*}{$\mathbf{0 , 0 5}$} & 0.00078 \\
\cline { 1 - 5 } Control group & Yo-yo (MAS) & $15.6 \pm 0,95$ & $15,9 \pm 1,0$ & 1.19 & & 0.3 \\
& SJ & $32,0 \pm 1,6$ & $32,0 \pm 2,0$ & 0.87 & & 0.0698 \\
& CMJ & $35,93 \pm 2,2$ & $36.03 \pm 2.1$ & 1.58 & & 0.085 \\
& RSA test & $6,62 \pm 0,32$ & $6.47 \pm 1.0$ & 2.22 & & 0.004 \\
\hline
\end{tabular}


Note: MAS - Maximal Aerobic Speed, SJ - Squat Jump, CMJ - Contre Mouvement Jump, RSA - Repeated Sprint Ability.

Table 2 presents the results obtained by the physical tests done with the experimental group and the control group before and after the training programme, we recorded a development in the experimental sample in the (MAS), vertical jump (CMJ), and (RSA) tests, while we did not record a significant difference in the vertical jump (SJ) test $(\mathrm{p}<0.05)$, As with the control sample, the development was limited to (MAS) and (RSA) only at $(\mathrm{p}<0.05)$.

Table 3: Results obtained by the physical tests done with the experimental group and the control group post the training programme.

\begin{tabular}{llllll}
\hline \multirow{2}{*}{ Tests } & $\begin{array}{l}\text { Experimental } \\
\text { group }\end{array}$ & Control group & T test & P value & Sig \\
\cline { 2 - 3 } & Post test & Post test & & & \\
\cline { 2 - 3 } Yo-yo (MAS) & $16.0 \pm 0.78$ & $15,9 \pm 1,0$ & 2.33 & & 0.0412 \\
SJ & $32,2 \pm 2,0$ & $32,0 \pm 2,0$ & 0.00 & $<\mathbf{0 , 0 5}$ & 0.700 \\
CMJ & $37.4 \pm 1.82$ & $36.03 \pm 2.1$ & 2.21 & & 0.0003 \\
RSA & $6.2 \pm 0.48$ & $6.47 \pm 1.0$ & 2.47 & & 0.004 \\
\hline
\end{tabular}

Table 3 presents the results obtained by the physical tests done with the experimental group and the control group post the training programme, where all tests are found to be statistically significant in favour of the experimental sample, with the exception of the (SJ) test, which was not statistically significant at $(\mathrm{p}<0,05)$.

\section{DISCUSSION}

The results of this study show that the training increases the (maximal aerobic speed, vertical jump in CMJ and the repeated sprint ability). The important and significant benefits in the experimental group and the control group between the starting situation and the final situation show a significant difference, Through these results, we presented a set of studies results that have a strong relationship to the hypothesis of our research. Billat and al study shows The intermittent method acts in the optimazation and the maintenance of the VO2 max (V. L. Billat et al., 2002)-(Grégory Dupont et al., 2003), in the development of the oxidative enzumes (Parolin et al., 1999). Likewise for the development of the time of reaction (Lemmink \& Visscher, 2005), these exercises are useful because they have an action on the peripherical component (Thompson et al., 1999). They also allow a mixed solicitation of the aerobic energetic stream (Gaitanos et al., 1993), and the anaerobic. The statistical calculations also show that, at the time of the 
test, a non significant improvement at $(p<0,05)$ was recorded between the experimental group and the control group. Contrary to our expectations, the differences of the oxygen consumption after the intermittent training by the exercises of plyomentrics are significantly different. However, both groups showed a slight improvement of the consumption of oxygen whatever the mode of training. On the account of that fact (Roberts et al., 1982), measured the economy to the run, following a training of plyometrics of six weeks with runners of medium distance running at intensity close to $70 \%$ of the V02max and he found an improvement of $6 \%$ of the running economy. The same writer mentioned that the mechanism behind this change could be the results of an improvement of the muscular tendinous rigidity of the lower limbs following the training of the plyometrics, which led to the improvement of the force of reaction and at lesser energetic cost. As the results of the tables 4.5 and 6 shows us a non significant difference $(\mathrm{p}<0,05)$ for the intergroup intra-group pre/post training tests is to be noted for the vertical spring in SJ. However, a significant difference is visible for the tests $\mathrm{CMJ}$ and $20 \mathrm{~m}(\mathrm{p}<0,01)$ intergroup and intra group for the experimental group and the control group. We can deduce that the intermittent training method by the exercises of plyometrics allowed the development of spring and speed. We can confirm the results because our study shows us that the experimental group improved its performances in SJ. We remind that the SJ is a test of vertical spring which doesn't show the quality of the neuro muscular stiffness whereas the jump in CMJ is a jump of vertical spring which involves the stiffness. Thus, we observe that the obtained difference between these two tests reflects the increase of the stiffness (Kubo et al., 2007), also observe that the increase of neuromuscular stiffness allows to significantly improve the performances of the explosive type. For the control group, no study shows a benefit of force or that of speed thanks to an aerobic work (Hickson et al., 1988)-(McCarthy et al., 1995), or of the type "explosive" (Paavolainen et al., 1999), on the effectiveness of the efforts of the aerobic type .Our results seem confirm these sentiments .Actually, we observe that the experimental group improved its maximal speed of run on $20 \mathrm{~m}$ in a more important way than the control group $(\mathrm{p}<0,05)$ and that the experimental group improved all the more its performances in the capacity of repeating sprints $(p<0,001)$ compared to the same group. Thus, we make an evident link between the increase in the run speed in sprint and the increase of the capacity of repeating them. We saw that the notion of tiredness was a determinant factor of the repeated sprints performance (Balsom et al., 1992). We also saw that the intermittent training based on the plyometrics allowed to improve the energetic efficiency of the athletes by an increase of the neuro-muscular stiffness. Our results are once more, in agreement with these sentiments because we observe in parallel an increase of the stiffness and an increase in the capacity to repeat sprints after a training period of 8 weeks in plyometrics. The repeat sprints ability (RSA) is a determinant factor of the performance in the football since with the 
intermittent method (repetition of sprints) there was improvement of the VO2 max, anaerobic qualities and also a reduction of the tiredness sign. Moreover, through the study of (Gaitanos et al., 1993), an intermittent training of type relays on the functionality of the myoglobin and the phosphate reserve, but after 6 to 8 $\mathrm{cm}$ of exercises, there is a majority solicitation of the aerobic glycolysis where one can improve the vo 2 max with a supra maximal intermittent work. From this we conclude that our outcomes are in agreement with the literature.

\section{CONCLUSION}

The requirement of modern football is still increasing. Actually we enumerated precedently the necessary physical qualities of the football players of high level. Amongst them, we can mainly notice the physical qualities of MAS maximal aerobic speed, of explosive force or the capacity to repeat sprints as well (Šibila et al., 2004). That's why in this study we are interested in the results which can bring a physical preparation based on the intermittent method by exercises of plyometrics on the footballers physical quality of the capacity to repeat sprints. Both groups developed the MAS through the method used during our research protocol, working by intermittent by exercises of plyometrics which improved the endurance, the capacity to repeat sprints and the anaerobic qualities or one works by the intermittent method which improved the endurance accompanied by a stabilization of the resistance to speed and the anaerobic qualities. If you apply it in terms of physical preparation specific to football, it's more beneficial to schedule intermittent sessions with exercises of plyometrics which allow the development of the force, the explosivity, the agility but also the development of the aerobic potential. In our study, we find the endurance as an aptitude to repeat intense and rapid efforts such as required by the modern football activity.

\section{REFERENCES}

1. Balsom, P. D., Seger, J. Y., Sjodin, B., \& Ekblom, B. (1992). Maximal-intensity intermittent exercise: Effect of recovery duration. International Journal of Sports Medicine. https://doi.org/10.1055/s-2007-1021311

2. BALSOM, P. D., SÖDERLUND, K., SJÖDIN, B., \& EKBLOM, B. (1995). Skeletal muscle metabolism during short duration high-intensity exercise: influence of creatine supplementation. Acta Physiologica Scandinavica. https://doi.org/10.1111/j.1748-1716.1995.tb09914.x

3. Bangsbo, J. (1994). The physiology of soccer - With special reference to intense intermittent exercise. Acta Physiologica Scandinavica, Supplement.

4. Bangsbo, Jens, Iaia, F. M., \& Krustrup, P. (2008). The Yo-Yo Intermittent Recovery Test. Sports Medicine. https://doi.org/10.2165/00007256-200838010-00004 
5. Billat, L. V. (2001). Interval training for performance: A scientific and empirical practice. Special recommendations for middle- and long-distance running. Part I: Aerobic interval training. In Sports Medicine. https://doi.org/10.2165/00007256-200131010-00002

6. Billat, V. L., Hamard, L., \& Koralsztein, J. P. (2002). The influence of exercise duration at VंO2 max on the off-transient pulmonary oxygen uptake phase during high intensity running activity. Archives of Physiology and Biochemistry. https://doi.org/10.1076/apab.110.5.383.11831

7. Bishop, D., Girard, O., \& Mendez-Villanueva, A. (2011). Repeated-sprint ability part II: Recommendations for training. In Sports Medicine. https://doi.org/10.2165/11590560-000000000-00000

8. Bosco, C., Belli, A., Astrua, M., Tihanyi, J., Pozzo, R., Kellis, S., Tsarpela, O., Foti, C., Manno, R., \& Tranquilli, C. (1995). A dynamometer for evaluation of dynamic muscle work. European Journal of Applied Physiology and Occupational Physiology. https://doi.org/10.1007/BF00618487

9. Bosco, Carmelo, Luhtanen, P., \& Komi, P. V. (1983). A simple method for measurement of mechanical power in jumping. European Journal of Applied Physiology and Occupational Physiology. https://doi.org/10.1007/BF00422166

10. Burgomaster, K. A., Hughes, S. C., Heigenhauser, G. J. F., Bradwell, S. N., \& Gibala, M. J. (2005). Six sessions of sprint interval training increases muscle oxidative potential and cycle endurance capacity in humans. Journal of Applied Physiology. https://doi.org/10.1152/japplphysiol.01095.2004

11. Canavan, P. K., \& Vescovi, J. D. (2004). Evaluation of power prediction equations: Peak vertical jumping power in women. Medicine and Science in Sports and Exercise. https://doi.org/10.1249/01.MSS.0000139802.96395.AC

12. Dawson, B., Fitzsimons, M., Green, S., Goodman, C., Carey, M., \& Cole, K. (1998). Changes in performance, muscle metabolites, enzymes and fibre types after short sprint training. European Journal of Applied Physiology and Occupational Physiology. https://doi.org/10.1007/s004210050402

13. De Villarreal, E. S. S., González-Badillo, J. J., \& Izquierdo, M. (2008). Low and moderate plyometric training frequency produces greater jumping and sprinting gains compared with high frequency. Journal of Strength and Conditioning Research. https://doi.org/10.1519/JSC.0b013e318163eade

14. Dupont, G, Berthoin, S., \& Gerbeaux, M. (2000). Performances lors d'un exercice intermittent anaerobie: comparaison entre enfants et sujets matures. / Performances during intermittent anaerobic exercise: comparison between children and mature subjects. Science $\&$ Sports.

15. Dupont, Grégory, Blondel, N., \& Berthoin, S. (2003). Performance for short intermittent runs: Active recovery vs. passive recovery. European Journal of Applied Physiology. https://doi.org/10.1007/s00421-003-0834-2

16. Dupont, Grégory, Millet, G. P., Guinhouya, C., \& Berthoin, S. (2005). Relationship between oxygen uptake kinetics and performance in repeated running sprints. European Journal of Applied Physiology. https://doi.org/10.1016/j.drugpo.2004.06.002

17. F.M., I., E., R., \& J., B. (2009). High-intensity training in football. International Journal of Sports Physiology and Performance. 
18. Gaitanos, G. C., Williams, C., Boobis, L. H., \& Brooks, S. (1993). Human muscle metabolism during intermittent maximal exercise. Journal of Applied Physiology. https://doi.org/10.1152/jappl.1993.75.2.712

19. Girard, O., Mendez-Villanueva, A., \& Bishop, D. (2011). Repeated-sprint ability part I: Factors contributing to fatigue. In Sports Medicine. https://doi.org/10.2165/11590550-000000000-00000

20. Harmer, A. R., McKenna, M. J., Sutton, J. R., Snow, R. J., Ruell, P. A., Booth, J., Thompson, M. W., Mackay, N. A., Stathis, C. G., Crameri, R. M., Carey, M. F., \& Eager, D. M. (2000). Skeletal muscle metabolic and ionic adaptations during intense exercise following sprint training in humans. Journal of Applied Physiology. https://doi.org/10.1152/jappl.2000.89.5.1793

21. Hickson, R. C., Dvorak, B. A., Gorostiaga, E. M., Kurowski, T. T., \& Foster, C. (1988). Potential for strength and endurance training to amplify endurance performance. Journal of Applied Physiology. https://doi.org/10.1152/jappl.1988.65.5.2285

22. Kotzamanidis, C. (2006). Effect of plyometric training on running performance and vertical jumping in prepubertal boys. Journal of Strength and Conditioning Research. https://doi.org/10.1519/R-16194.1

23. Krustrup, P., Mohr, M., Amstrup, T., Rysgaard, T., Johansen, J., Steensberg, A., Pedersen, P. K., \& Bangsbo, J. (2003). The Yo-Yo intermittent recovery test: Physiological response, reliability, and validity. Medicine and Science in Sports and Exercise. https://doi.org/10.1249/01.MSS.0000058441.94520.32

24. Kubo, K., Morimoto, M., Komuro, T., Yata, H., Tsunoda, N., Kanehisa, H., \& Fukunaga, T. (2007). Effects of plyometric and weight training on muscle-tendon complex and jump performance. Medicine and Science in Sports and Exercise. https://doi.org/10.1249/mss.0b013e31813e630a

25. Lemmink, K. A. P. M., \& Visscher, C. (2005). Effect of intermittent exercise on multiple-choice reaction times of soccer players. Perceptual and Motor Skills. https://doi.org/10.2466/PMS.100.1.85-95

26. Linossier, M. T., Dormois, D., Geyssant, A., \& Denis, C. (1997). Performance and fibre characteristics of human skeletal muscle during short sprint training and detraining on a cycle ergometer. European Journal of Applied Physiology and Occupational Physiology. https://doi.org/10.1007/s004210050194

27. Macdougall, J. D., Hicks, A. L., Macdonald, J. R., Mckelvie, R. S., Green, H. J., \& Smith, K. M. (1998). Muscle performance and enzymatic adaptations to sprint interval training. Journal of Applied Physiology. https://doi.org/10.1152/jappl.1998.84.6.2138

28. McCarthy, J. P., Agre, J. C., Graf, B. K., Pozniak, M. A., \& Vailas, A. C. (1995). Compatibility of Actaptive responses with combining strength and endurance training. Medicine and Science in Sports and Exercise. https://doi.org/10.1249/00005768-199503000-00021

29. Mujika, I., \& Padilla, S. (2003). Scientific bases for precompetition tapering strategies. Medicine and Science in Sports and Exercise. https://doi.org/10.1249/01.MSS.0000074448.73931.11

30. Paavolainen, L., Häkkinen, K., Hämäläinen, I., Nummela, A., \& Rusko, H. (1999). Explosive-strength training improves 5-km running time by improving running economy and muscle power. Journal of Applied Physiology. https://doi.org/10.1152/jappl.1999.86.5.1527 
31. Parolin, M. L., Chesley, A., Matsos, M. P., Spriet, L. L., Jones, N. L., \& Heigenhauser, G. J. F. (1999). Regulation of skeletal muscle glycogen phosphorylase and PDH during maximal intermittent exercise. American Journal of Physiology Endocrinology and Metabolism. https://doi.org/10.1152/ajpendo.1999.277.5.e890

32. Parra, J., Cadefau, J. A., Rodas, G., Amigó, N., \& Cussö, R. (2000). The distribution of rest periods affects performance and adaptations of energy metabolism induced by high-intensity training in human muscle. Acta Physiologica Scandinavica. https://doi.org/10.1046/j.1365-201X.2000.00730.x

33. Rahimi, R. (2005). Effect of different rest intervals on the exercise volume completed during squat bouts. Journal of Sports Science and Medicine.

34. Roberts, A. D., Billeter, R., \& Howald, H. (1982). Anaerobic muscle enzyme changes after interval training. International Journal of Sports Medicine. https://doi.org/10.1055/s-2008-1026055

35. Rodas, G., Ventura, J. L., Cadefau, J. A., Cussó, R., \& Parra, J. (2000). A short training programme for the rapid improvement of both aerobic and anaerobic metabolism. European Journal of Applied Physiology. https://doi.org/10.1007/s004210000223

36. Šibila, M., Vuleta, D., \& Pori, P. (2004). Position-Related Differences in Volume and Intensity of Large-Scale Cyclic Movements of Male Players in Handball. Kinesiology.

37. Spencer, M., Bishop, D., Dawson, B., \& Goodman, C. (2005). Physiological and metabolic responses of repeated-sprint activities: Specific to field-based team sports. In Sports Medicine. https://doi.org/10.2165/00007256-20053512000003

38. Spurrs, R. W., Murphy, A. J., \& Watsford, M. L. (2003). The effect of plyometric training on distance running performance. / Effet de l'entrainement pliometrique sur les performances en course de fond. European Journal of Applied Physiology.

39. Stølen, T., Chamari, K., Castagna, C., \& Wisløff, U. (2005). Physiology of soccer: An update. In Sports Medicine. https://doi.org/10.2165/00007256-20053506000004

40. Thompson, D., Nicholas, C. W., \& Williams, C. (1999). Muscular soreness following prolonged intermittent high-intensity shuttle running. Journal of Sports Sciences. https://doi.org/10.1080/026404199365902

41. Withers, R., Maricic, Z., Wasilewski, S., \& Kelly, L. (1982). Match analyses of australians professional soccer players. Journal Human Movement Studies. 


\title{
ВЛИЯНИЕ ПЕРИОДИЧЕСКИХ ТРЕНИРОВОК С ПЛИОМЕТРИЧЕСКИМИ УПРАЖНЕНИЯМИ НА АЭРОБНЫЕ И АНАЭРОБНЫЕ СПОСОБНОСТИ
}

\begin{abstract}
АННОТАЦИЯ
В данном исследовании выявлена эффективность периодической работы как ключевого качественного метода путем организации плиометрической работы. Проблема заключается в том, чтобы найти научно обоснованные методы обучения, которые приводят к улучшению этих качеств. Выдвинута гипотеза, что периодические тренировки с помощью плиометрических упражнений способствуют улучшению аэробных и анаэробных способностей футболистов.
\end{abstract}

К участию в данном исследовании были приглашены двадцать футболистов в возрасте от 18 до 23 лет из команды университета Тиссемсилт (таблица 1), которые были методом случайной выборки разделены на 2 группы: экспериментальная группа (ЭГ) и контрольная группа (КГ). Программа была разработана на 8 недель и спланирована следующим образом: две недели периодической работы 10 c/20 с, четыре недели периодической работы 30 c/30 с, две недели периодической работы 15 c/30 c. Частотность данных видов обучения составляла 2 сеанса в неделю. Футболисты прошли физические тесты: (SJ; CMJ). Тест (RSA) и тест Йо-йо. Футболисты вновь прошли тестирование, что позволило сравнить полученные результаты между двумя тестами - до и после тренировки.

После восьми недель тренировок было отмечено развитие в экспериментальной выборке в тестах (MAS), вертикальном прыжке (CMJ) и (RSA), в то время как не было зафиксировано достоверной разницы в тесте вертикального прыжка (SJ) (p<0,05), как и в контрольной выборке, развитие было ограничено только (MAS) и (RSA).

Это исследование показывает эффективность тренировочной программы, примененной к экспериментальной выборке в посттестах между двумя группами, за исключением теста на вертикальный прыжок (SJ), где не отмечено существенной разницы.

Ключевые слова: Прерывистые, Плиометрические, Упражнения, Аэробные, Анаэробные. 